\title{
Article \\ The Growth Response of Pasture Brome (Bromus valdivianus Phil.) to Defoliation Frequency under Two Soil-Water Restriction Levels
}

\author{
Javier García-Favre * (D), Ignacio F. López, Lydia M. Cranston, Daniel J. Donaghy and Peter D. Kemp \\ School of Agriculture and Environment, Massey University, Private Bag 11-2221, \\ Palmerston North 4440, New Zealand; I.F.Lopez@massey.ac.nz (I.F.L.); L.Cranston@massey.ac.nz (L.M.C.); \\ D.J.Donaghy@massey.ac.nz (D.J.D.); p.kemp@massey.ac.nz (P.D.K.) \\ * Correspondence: J.Favre@massey.ac.nz
}

Citation: García-Favre, J.; López, I.F.; Cranston, L.M.; Donaghy, D.J.; Kemp, P.D. The Growth Response of Pasture Brome (Bromus valdivianus Phil.) to Defoliation Frequency under Two Soil-Water Restriction Levels. Agronomy 2021, 11, 300. https:// doi.org/10.3390/agronomy11020300

\section{Academic Editor:}

Giovanni Mauromicale

Received: 18 January 2021

Accepted: 5 February 2021

Published: 8 February 2021

Publisher's Note: MDPI stays neutral with regard to jurisdictional claims in published maps and institutional affiliations.

Copyright: (c) 2021 by the authors. Licensee MDPI, Basel, Switzerland. This article is an open access article distributed under the terms and conditions of the Creative Commons Attribution (CC BY) license (https:// creativecommons.org/licenses/by/ $4.0 /)$.

\begin{abstract}
Pasture brome (Bromus valdivianus Phil.) has the potential to increase current levels of herbage production and pasture persistence in New Zealand dryland, well-drained soils. However, there is little literature on the effect of defoliation management on growth of this grass under contrasting soil-water restriction levels. The growth physiology and performance of pasture brome were evaluated in pots in a glasshouse. Defoliation frequency (DF) treatments were applied based on three different accumulated growing degree-days (AGDD): 250, 500 and 1000 AGDD (high, medium, and low DF). At end of the first growing cycle (1000 AGDD), water availability was restricted to $20-25 \%$ of field capacity (FC) in half of the pots, while the other pots were maintained between $80-85 \%$ FC. Total accumulated herbage mass was positively related with the low DF and well-watered conditions $(p<0.05)$. At the final harvest, plants subjected to low DF had greater root mass than high and medium DF $(p<0.05)$. At each harvest, the leaf regrowth stage (LS) for low DF was 3.5, while for high and medium DF, the LS was 1.5 and 2.0; respectively. Tiller water-soluble carbohydrates were highest at the low DF and under 20-25\% FC. Regardless of soil-water conditions, defoliation at 3.5 LS supports production, enhancing survival during a drought.
\end{abstract}

Keywords: drought; leaf regrowth stage; tiller survival; perennial grass; management; root growth

\section{Introduction}

Bromes (Bromus spp.) are genus of grass species that include some useful forage types, as well as some weedy species. Bromus valdivianus Phil. (Bv) is native to the temperate humid region of Chile. It has similar agricultural attributes to perennial ryegrass Lolium perenne L. (accumulated herbage mass production, herbage quality) but produces more herbage mass during soil-water restriction periods, such as summer [1]. However, previous research on Bv in New Zealand has shown it produced less total herbage mass than other perennial grasses, such as Dactylis glomerata L. and Festuca arundinacea Schreb., when grown in hill country under dry summer conditions [2]. Further, it exhibited poorer survival than D. glomerata when sown in a mix with Medicago sativa L. in hill country in the Canterbury region with an average rainfall of $643 \mathrm{~mm} /$ year [3]. However, in both of these studies, all the species were defoliated at the same time without considering species-specific defoliation intervals. The frequency and intensity of defoliation are key factors that determine the production and persistence of forage species [4]. Unsuitable defoliation frequency leads to depletion of perennial grass species soluble carbohydrate reserves and low root mass resulting in poor survival during drought and slow recover after it [5].

Defoliation frequency based on leaf regrowth stage (LS) aligns perennial grass species plant physiology with production and persistence, such that the regrowth post-defoliation is based on the plant recovery of its water-soluble carbohydrate (WSC) reserves. This defoliation strategy supports persistence in fast-growing grass species [6]. The recovery of 
the WSC reserves in plants during the regrowth period after defoliation is what determines the lower range of LS recommended for grazing [7]. Bromus valdivianus Phil is a six-leaf species with an optimum LS range for defoliation between 3 and 4 [8]. However, that research did not address below-ground morphological changes, such as root biomass, or plant energy reserves (WSC in the stubble) in relation to LS defoliation criteria. It is well known that resource allocation to roots is not a priority immediately after defoliation for perennial grass species $[7,9]$. Further, frequent defoliation mostly affects elongation and survival of roots, resulting in a plant with a poor root system [7], which is expected to negatively impact plant survival under water stress conditions.

Forage species have diverse strategies when faced with soil-water restriction and increasing temperatures. The primary strategies of plants are drought escape, dehydration avoidance and dehydration tolerance [10]. Temperate grasses, subjected to moderate to low soil moisture levels, express dehydration avoidance through developing a deeper root and leaf osmotic adjustment. If soil moisture levels continue decreasing, the plants start a drought-survival phase, where growth is suppressed as the energy is allocated to the growing point of stems (dehydration tolerance) [11]. A common strategy observed in some grasses, such as Dactylis glomerata L., to survive an intense drought is the accumulation of WSC in the meristem tissues of leaves [12,13]. The reserve of WSC in the stubble also play a specific role in the fast recovery of growth when a drought ends [14]. Little is known about the interaction between defoliation frequency and soil-water content on $\mathrm{Bv}$ growth and survival. It is hypothesised that infrequent defoliations would result in plants with more extensive root systems and a full replenishment of WSC that would allow them to survive low soil-water availability. The aim of the present study was to evaluate $\mathrm{Bv}$ production, resource allocation within the plant and WSC reserve levels under three contrasting defoliation frequencies and two soil-water restriction levels in a glasshouse study.

\section{Materials and Methods}

\subsection{Treatments and Experimental Design}

The experiment was in a glasshouse at Massey University's Plant Growth Unit, School of Agriculture and Environment $\left(-40.37^{\circ}\right.$ latitude south and $175.61^{\circ}$ longitude west) under natural light conditions from 9 October 2018 to 12 March 2019. A total of 66 pots, of $8 \mathrm{~L}$ capacity ( $24 \mathrm{~cm}$ upper diameter, $17 \mathrm{~cm}$ lower diameter and $24 \mathrm{~cm}$ height) were filled with a mixture of $30 \%$ Manawatu silt loam soil and $70 \%$ fine sand to achieve sandy-loam texture. The results of the chemical analysis of the substrate were as follows: $\mathrm{pH} 6.3$ (1:2 [soil:water]), $35 \mathrm{mg} \mathrm{L}^{-1}$ Olsen $\mathrm{P}, 0.34 \mathrm{me} 100 \mathrm{~g}^{-1}$ potassium, 2.4 me $100 \mathrm{~g}^{-1}$ calcium, $0.6 \mathrm{me} 100 \mathrm{~g}^{-1}$ magnesium, 3 me $100 \mathrm{~g}^{-1}$ cation exchange capacity and $83 \mathrm{mg} \mathrm{kg}^{-1}$ sulphate sulphur. Based on this analysis, the following fertiliser was added to each $60 \mathrm{~L}$ of substrate: $120 \mathrm{~g}$ of slow-release formula ( $14 \%$ nitrogen $(\mathrm{N}), 5 \% \mathrm{P}, 10 \%$ soluble potash, $0.5 \%$ magnesium, $3.2 \%$ sulphur, $1.6 \%$ iron and $0.3 \%$ manganese), $60 \mathrm{~g}$ short term formula ( $14 \%$ total $\mathrm{N}, 6 \% \mathrm{P}$, $11.6 \%$ potassium, $1 \%$ magnesium, $4 \%$ sulphur, $1 \%$ iron and $0.5 \%$ manganese), and $90 \mathrm{~g}$ of dolomite. In each pot, two seeds of $\mathrm{Bv}$ cv. Bareno were sown in 24 equidistant positions, with $40 \mathrm{~mm}$ between them. At the early plantlet establishment stage, the number of plants per pot was thinned to one plant per position.

A combination of three defoliation frequencies and two soil-water restriction levels $(2 \times 3$ factorial arrangement; six treatments) were applied in a complete randomised block design with four replicates. A previous glasshouse study found that Bv needs less than 1000 accumulated growing degree-days (AGDD) to produce the six live leaves that each tiller maintains [8]. Based on that information, three defoliation frequency targets were applied: high (250 AGDD), medium (500 AGDD) and low (1000 AGDD). The temperature inside the glasshouse was recorded daily at 10-min intervals. Thus, AGDD was calculated adding the average of maximum and minimum temperatures per day, following the method by [15]. The average temperature was $22.5^{\circ} \mathrm{C}$ for the experimental period, while maximum and minimum were $27.8^{\circ} \mathrm{C}$ and $17.2^{\circ} \mathrm{C}$; respectively. 
Two water restriction levels were applied: $80-85 \%$ of field capacity (FC) and $20-25 \%$ FC. The $80-85 \%$ FC was the control for the soil water restriction treatment. The soil-water contents were continuously monitored by $\mathrm{ECH}_{2} \mathrm{O}$ EC-5 soil-moisture sensors at $10 \mathrm{~cm}$ depth in the soil at the centre of 12 pots, recording data every $15 \mathrm{~min}$. The soil-moisture levels in each treatment were readjusted daily by irrigation according to the following formula:

$$
I=([\mathrm{IC}-\mathrm{WC}] / 100) \times \mathrm{BD} \times \mathrm{SD} \times \mathrm{PA}
$$

where $I=$ irrigation $\left(\mathrm{L} \mathrm{m}^{-2}\right)$; IC = irrigation criteria (vol. \%); WC = substrate water content (vol. \%); $\mathrm{BD}=$ bulk density $\left(\mathrm{mg} \mathrm{m}^{-3}\right) ; \mathrm{SD}=$ substrate depth $(\mathrm{m}) ; \mathrm{PA}=$ pot area $\left(0.045 \mathrm{~m}^{2}\right)$.

The period of water restriction was comparable to the total number of days per year with a soil-moisture deficit in Palmerston North based on data collected from 2001 to 2018 (67 days per year; collected from the NIWA/Ag Research Weather Station, Agent No. 21963, Palmerston North, 2019).

Following sowing, three experimental stages were implemented.

(a) From sowing to the first harvest (H0): During this period, the plants grew for 9 weeks without environmental restrictions. Each Bv tiller maintained 6 live leaves at the same time: 3 fully expanded leaves, 2 expanding leaves and 1 emerging leaf; when the 7 th leaf appeared, the older leaf began to senesce. Thus, $\mathrm{H} 0$ occurred when the 6th Bv leaf appeared in the older tillers. At this moment, all the plants were defoliated to 50-mm height, marking the beginning of the experimental period.

(b) Period from H0 to H1: In this period, three defoliation frequency treatments were imposed. This period ended (H1) with all plants being manually defoliated and occurred when 1000 AGGD was achieved, meaning that the medium defoliation frequency was defoliated twice and the high defoliation frequency was defoliated 4 times. This period was utilised as a pre-treatment cycle to adapt the plants to the different defoliation frequencies before the application of soil-water treatments.

(c) Period from $\mathrm{H} 1$ to $\mathrm{H} 2$ : The soil-water restriction treatments were applied until the longest defoliation treatment had grown through one full regrowth cycle (1000 AGDD). During this period, the medium defoliation frequency was again defoliated twice and the high defoliation frequency was again defoliated 4 times.

\subsection{Evaluated Variables}

The herbage and root measurements performed in the period $\mathrm{H} 1-\mathrm{H} 2$ were as follows: At $\mathrm{H} 1$, individual tillers were marked at their base with a paper clip in two plants located in the centre of each pot and every three days the leaf length, number of leaves and leaf appearance were recorded. The leaf length of an elongating leaf included the distance from the ligule of the previous fully expanded leaf to the lamina tip, and for a fully expanded leaf considered the distance from the ligule to its tip. This was performed in every leaf per marked tiller. If a marked tiller died, it was replaced with another tiller that visually represented the mean population. The number of tillers per plant was counted once a week in the two central plants of each pot. Herbage at each defoliation event was dried at $70{ }^{\circ} \mathrm{C}$ for $48 \mathrm{~h}$ or until constant weight was reached. At the end of the study, total herbage mass accumulation was calculated for each defoliation treatment by adding the dried herbage from each defoliation event (four events for high, two for medium, and one for low defoliation frequencies). At the end of the $\mathrm{H} 2$ period, the two marked tillers per pot were cut at ground level and the leaf area (considering only the lamina), leaf weight, and specific leaf area (SLA; leaf area/unit weight) were determined. Leaf area was measured using a leaf area meter (LI-COR 3100, area meter). In order to compare between defoliation treatments, the variables were standardised using growing degree days according to Tsimba et al. [16]: leaf area expansion $\left(\mathrm{mm}^{2}{ }^{\circ} \mathrm{Cd}^{-1}\right), \mathrm{SLA}\left(\mathrm{mm}^{2} \mathrm{mg}^{-1}{ }^{\circ} \mathrm{Cd}^{-1}\right)$ and changes in leaf weight $\left(\mathrm{mg}^{\circ} \mathrm{Cd}^{-1}\right)$. These variables were calculated by dividing the $\mathrm{H} 2$ collected data by the thermal time elapsed in each defoliation treatment. Leaf elongation rate $\left(\mathrm{mm}^{\circ} \mathrm{Cd}^{-1}\right)$ was calculated as the sum of leaf length between $\mathrm{H} 1$ and $\mathrm{H} 2$ (measured 
every three days) divided by the thermal time in each defoliation treatment. The remaining sward in each pot was cut to $50 \mathrm{~mm}$. The stubble (tiller base below the $50-\mathrm{mm}$ defoliation height) was frozen with liquid nitrogen before freeze-drying. The freeze-dried samples were then weighed, ground through a 1-mm sieve and sent to the Massey University Nutrition Laboratory (Palmerston North, New Zealand) where WSC concentration was obtained using the colorimetric assays developed by Somogyi-Nelson [17].

Above-ground foliage mass and root mass per plant on a dry-weight basis were measured from one centre plant from each of three spare pots per treatment at $\mathrm{H} 2$. These spare pots, 18 in total, were kept under the same conditions and treatments as the experimental pots. The roots were washed and scanned at $400 \mathrm{dpi}$ with a scanner (Perfection V800 Photo, Epson), and the images were analysed with Winrhizo software (ver. 2012b, Regent Instruments Inc., Quebec, Canada) to determine total root length, root surface area, root diameter and root volume.

\subsection{Statistical Analysis}

Using R Statistic [18], a one-way analysis of variance (ANOVA) and least significant difference (LSD) were used to analyse statistical differences with a level of significance of $5 \%(p=0.05)$. Principal component analysis (PCA) was performed to recognise differences among treatments, as well as to detect the extent that each variable explained the variation between treatments. First, all the variables were standardised and then the analysis conducted with prcomp function in R software [18].

\section{Results}

\subsection{Herbage Mass and Tiller Components}

Accumulated herbage mass per pot increased by $32 \%$ under low defoliation frequency, with no significant differences between the high and medium defoliation frequencies. In addition, low soil-water levels reduced accumulated herbage mass by $47 \%$ (Table 1). Tiller number per plant was not affected by any of the treatments.

On an individual tiller basis, leaf area and SLA significantly increased under more frequent defoliation. As expected, leaf regrowth stage (LS) significantly increased (there were more leaves) as defoliation frequency decreased. There was no significant effect of defoliation frequency on leaf weight and leaf length.

Table 1. Herbage mass accumulation per pot and tiller components of Bromus valdivianus Phil. grown under three defoliation frequencies (Df) (250 [high], 500 [medium] and 1000 [low] accumulated growing degree days) and two levels of soil water content (Wl) (80-85\% and $20-25 \%$ of field capacity [FC]).

\begin{tabular}{|c|c|c|c|c|c|c|c|}
\hline & $\begin{array}{l}\text { Herbage Mass } \\
\left(g^{-1} \text { pot }^{-1}\right)\end{array}$ & $\begin{array}{c}\text { Leaf Area } \\
\text { Rate/Tiller } \\
\left(\mathrm{mm}^{2}{ }^{\circ} \mathbf{C d}^{-1}\right)\end{array}$ & $\begin{array}{l}\text { Leaf Weight } \\
\text { Rate/Tiller } \\
\left(\mathrm{mg}^{\circ} \mathrm{Cd}^{-1}\right)\end{array}$ & $\begin{array}{l}\text { Leaf } \\
\text { Regrowth } \\
\text { Stage }\end{array}$ & $\begin{array}{c}\text { Specific Leaf Area } \\
\text { Rate }\left(\mathrm{mm}^{2} \mathrm{mg}^{-1}\right. \\
\left.{ }^{\circ} \mathrm{Cd}^{-1}\right)\end{array}$ & $\begin{array}{l}\text { Leaf Length } \\
\text { Rate }(\mathrm{mm} \\
\left.{ }^{\circ} \mathrm{Cd}-1\right)\end{array}$ & $\begin{array}{c}\text { Tillers } \\
\text { No./Plant }\end{array}$ \\
\hline \multicolumn{8}{|l|}{$\begin{array}{c}\text { Defoliation frequency } \\
\text { (Df) } \\
\text { (AGDD) }\end{array}$} \\
\hline 250 (High) & $2.3 \mathrm{~b}$ & $2.24 \mathrm{a}$ & 0.17 & $1.34 \mathrm{c}$ & $0.054 \mathrm{a}$ & 0.31 & 4.69 \\
\hline 500 (Medium) & $2.7 \mathrm{~b}$ & $1.89 \mathrm{ab}$ & 0.15 & $1.73 \mathrm{~b}$ & $0.025 \mathrm{~b}$ & 0.34 & 4.38 \\
\hline 1000 (Low) & $4.2 \mathrm{a}$ & $1.44 \mathrm{~b}$ & 0.11 & $2.95 \mathrm{a}$ & $0.011 \mathrm{c}$ & 0.38 & 4.06 \\
\hline Significance & $* *$ & $*$ & ns & $* * *$ & $* * *$ & ns & ns \\
\hline \multicolumn{8}{|l|}{ Water level (Wl) } \\
\hline $20-25 \%$ FC & $2.3 \mathrm{~b}$ & $1.54 \mathrm{~b}$ & 0.14 & $1.76 \mathrm{~b}$ & $0.026 \mathrm{~b}$ & $0.22 \mathrm{~b}$ & 4.08 \\
\hline $80-85 \%$ FC & $3.9 \mathrm{a}$ & $2.18 \mathrm{a}$ & 0.15 & $2.29 \mathrm{a}$ & $0.034 \mathrm{a}$ & $0.46 \mathrm{a}$ & 4.67 \\
\hline $\begin{array}{l}\text { Significance } \\
\text { Df } \times W l\end{array}$ & $* *$ & $* *$ & ns & $* * *$ & $*$ & $* * *$ & ns \\
\hline $250 \times 20-25 \% \mathrm{FC}$ & 1.5 & 1.75 & 0.15 & $1.21 \mathrm{~d}$ & 0.048 & 0.18 & 4.25 \\
\hline $250 \times 80-85 \%$ FC & 3.0 & 2.73 & 0.18 & $1.44 \mathrm{~d}$ & 0.060 & 0.44 & 5.13 \\
\hline $500 \times 20-25 \%$ FC & 2.2 & 1.73 & 0.15 & $1.50 \mathrm{~d}$ & 0.022 & 0.23 & 3.75 \\
\hline $500 \times 80-85 \%$ FC & 3.2 & 2.04 & 0.15 & $1.97 \mathrm{c}$ & 0.028 & 0.45 & 5.00 \\
\hline $1000 \times 20-25 \% \mathrm{FC}$ & 3.1 & 1.12 & 0.12 & $2.44 \mathrm{~b}$ & 0.009 & 0.27 & 4.25 \\
\hline $1000 \times 80-85 \% \mathrm{FC}$ & 5.2 & 1.77 & 0.14 & $3.47 \mathrm{a}$ & 0.013 & 0.49 & 3.88 \\
\hline Significance & ns & ns & ns & * & ns & ns & ns \\
\hline
\end{tabular}

Letters that differ within columns indicate values that are significantly different at the following levels: ${ }^{*} p \leq 0.05 ;{ }^{* *} p \leq 0.01 ;{ }^{* * *} p \leq 0.001$; ns, not significant $(p>0.05)$. 
Water restriction significantly decreased leaf area (30\%), LS (25\%), SLA (25\%) and leaf length $(25 \%)$ but had no significant effect on individual leaf weight. In addition, there was a significant interaction between defoliation frequency and water restriction, only on LS, with more leaves/tiller present for the combination of more water, and longer defoliation intervals (Table 1).

\subsection{Plant Structure at Final Harvest (H2)}

Most above- and below-ground traits, such as above-ground foliage mass, root length, root surface area and root volume were not significantly affected by defoliating the plants at either medium or low defoliation frequencies; however, all of these measurements were significantly reduced by defoliating at high frequency (Table 2). Root mass per plant was 1.5 times greater under low defoliation frequency than the medium, and 3 times greater than the high defoliation frequency. Root diameter was not significantly affected by defoliation frequency and water level, but all other traits were reduced under $20-25 \%$ FC (Table 2). The interaction between main effects was not significant $(p>0.05)$ for above ground biomass, root mass, total root length, root surface area, root diameter, root volume and WSC.

Table 2. Above- and below-ground components of Bromus valdivianus Phil. subjected to three defoliation frequencies (250 [high], 500 [medium] and 1000 [low] accumulated growing degree days) and two soil-water level conditions: 80-85\% field capacity (FC) and $20-25 \%$ FC, at final harvest (H2).

\begin{tabular}{|c|c|c|c|c|c|c|c|}
\hline & $\begin{array}{l}\text { Above Ground } \\
\text { Foliage Mass } \\
\left(\text { g DM plant }^{-1}\right)\end{array}$ & $\begin{array}{l}\text { Root Mass } \\
\text { (g DM } \\
\left.\text { plant }^{-1}\right)\end{array}$ & $\begin{array}{l}\text { Total Root } \\
\text { Length } \\
(\mathrm{cm})\end{array}$ & $\begin{array}{c}\text { Root } \\
\text { Surface } \\
\text { Area }\left(\mathrm{cm}^{2}\right)\end{array}$ & $\begin{array}{c}\text { Root } \\
\text { Diameter } \\
(\mathrm{mm})\end{array}$ & $\begin{array}{c}\text { Root } \\
\text { Volume } \\
\left(\mathrm{cm}^{3}\right)\end{array}$ & $\begin{array}{c}\text { WSC } \\
\left(\mathrm{mg} \mathrm{tiller}^{-1}\right)\end{array}$ \\
\hline \multicolumn{8}{|c|}{$\begin{array}{l}\text { Defoliation frequency } \\
\text { (AGDD) }\end{array}$} \\
\hline 250 (High) & $0.49 \mathrm{~b}$ & $0.18 \mathrm{c}$ & $1422.8 \mathrm{~b}$ & $90.4 \mathrm{~b}$ & 0.21 & $0.47 \mathrm{~b}$ & $2.04 \mathrm{c}$ \\
\hline 500 (Medium) & $1.24 \mathrm{a}$ & $0.37 \mathrm{~b}$ & $3061.7 \mathrm{a}$ & $225.2 \mathrm{a}$ & 0.23 & $1.33 \mathrm{a}$ & $3.22 \mathrm{~b}$ \\
\hline $1000($ Low $)$ & $1.45 \mathrm{a}$ & $0.55 \mathrm{a}$ & $4092.9 \mathrm{a}$ & $298.5 \mathrm{a}$ & 0.23 & $1.76 \mathrm{a}$ & $12.53 \mathrm{a}$ \\
\hline Significance & $*$ & $* * *$ & $* *$ & $* * *$ & ns & $* * *$ & $* * *$ \\
\hline \multicolumn{8}{|l|}{ Water level } \\
\hline $20-25 \% \mathrm{FC}$ & $0.80 \mathrm{~b}$ & $0.31 \mathrm{~b}$ & $2280.4 \mathrm{~b}$ & $156.1 \mathrm{~b}$ & 0.22 & $0.86 \mathrm{~b}$ & $6.20 \mathrm{a}$ \\
\hline $80-85 \%$ FC & $1.32 \mathrm{a}$ & $0.42 \mathrm{a}$ & 3437.9 a & $253.4 \mathrm{a}$ & 0.23 & $1.51 \mathrm{a}$ & $4.95 \mathrm{~b}$ \\
\hline Significance & $*$ & $*$ & $*$ & $* *$ & ns & $* *$ & $* * *$ \\
\hline
\end{tabular}

Letters that differ within columns indicate values that are significantly different at the following levels: ${ }^{*} p \leq 0.05 ;{ }^{* *} p \leq 0.01 ;{ }^{* * *} p \leq 0.001$; ns, not significant $(p>0.05)$.

There was a strong linear relationship between tiller base weight and total WSC ( $\mathrm{mg} /$ tiller). The WSC significantly increased when the defoliation frequency decreased and was also greater by a factor of $20 \%$ per tiller in plants growing at $20-25 \% \mathrm{FC}$, compared to those growing at $80-85 \%$ FC (Table 2). The highest value for WSC occurred under water restriction and low defoliation frequency $(13.5 \mathrm{mg})$; while the lowest value occurred in plants defoliated at the high frequency under well-watered conditions $(1.1 \mathrm{mg})$. In addition, tiller weight showed the same trend as WSC, increasing with a decrease in defoliation frequency, and with water restriction. However, plants defoliated at the low frequency did not exhibit WSC differences between both water treatments (Figure 1).

In the PCA, the principal components 1 (PC1, which discriminated the treatments according to frequency of defoliation) and 2 ( $\mathrm{PC} 2$, which discriminated the treatments according to soil water restriction), explained $90 \%$ of the total variation between treatments. Measured variables with coefficients higher than 0.25 were considered as a contributor to data pattern description. In PC1, which explained $72.3 \%$ of the variation, the variables that explained most of the differences between treatments were associated with root size and weight, LS, accumulated herbage mass and WSC. Plants defoliated at the medium defoliation frequency under well-watered conditions and plants defoliated at low defoliation frequency under both water treatments were positively associated with those variables. Then, plants growing under low defoliation frequency and $20-25 \%$ FC had similar root characteristics, LS and accumulated herbage mass to plants defoliated at the medium frequency under $80-85 \%$ FC. In PC2, which explained $18.3 \%$ of the variation, only WSC 
was positively related to $20-25 \%$ FC, while leaf area and leaf length rate were to $80-85 \%$ FC and to defoliations at the high and medium frequencies (Figure 2).

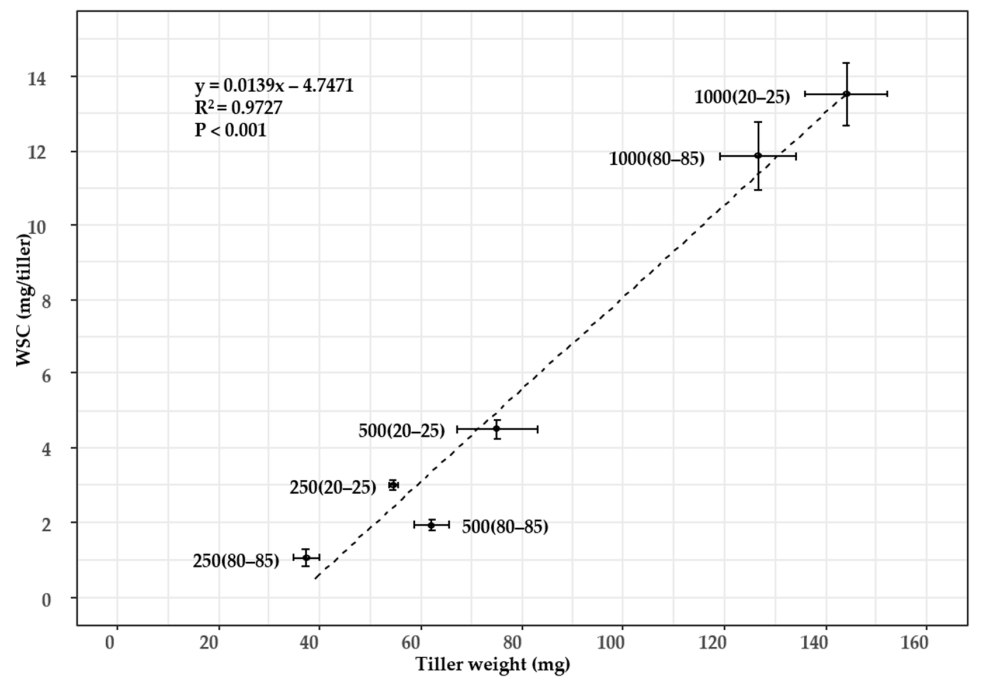

Figure 1. Relationship between weight of tiller base and water-soluble carbohydrates (WSC) per Table 250. [high], 500 [medium] and 1000 [low] accumulated growing degree days) and two soil water levels: $80-85 \%$ field capacity (FC) and $20-25 \%$ FC. The standard error for WSC is shown as vertical bars, and the standard error for tiller weight is shown as horizontal bars.

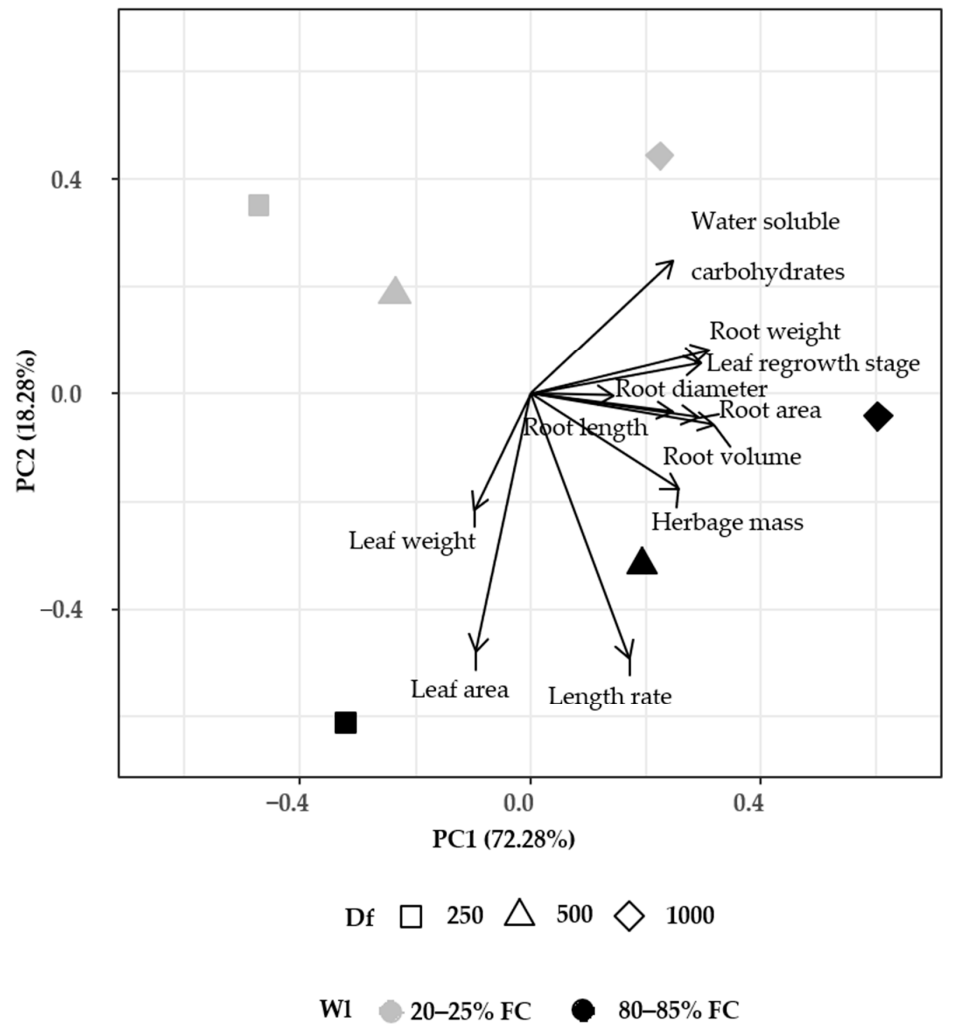

Figure 2. Principal component analysis showing changes in the growth variables and their relationship for Bromus valdivianus Phil. due to defoliation frequency (Df) based on accumulated growing degree days: 250 (high) $(\square), 500$ (medium) $(\triangle)$ and 1000 (low) $(\diamond)$ accumulated growing degree days, and two levels of soil-water restriction (Wl): 80-85\% field capacity (FC) (shaded black) and 20-25\% FC (shaded grey). 


\section{Discussion}

This glasshouse study highlighted the effect of defoliation frequency on Bv plant growth and structure. Defoliation frequency during a period of soil-water scarcity has previously been shown to have a significant effect in terms of plant fitness to survive and recovery [6]. Results of the WSC reserve status supported the optimal LS range (3-4) suggested by Ordoñez et al. [8] and provided further evidence for managing defoliation frequency in accordance with LS criteria. In a study of defoliation frequency effects based on LS for different grass species, Turner et al. [19] showed the importance of species-specific defoliation intervals. Poor productivity and persistence of Bv in field experiments in New Zealand [2,3] could be a consequence of defoliation management based on other species, e.g., perennial ryegrass.

The finding that infrequent defoliation allowed a greater tiller weight and thus a greater WSC content (Figure 1) indicates how the priority of energy allocation in the plant changes during regrowth after defoliation, which supports earlier findings by Danckwerts and Gordon [20]. Donaghy and Fulkerson [7] stated that leaf regrowth in perennial grasses has the highest priority for WSC reserves immediately after defoliation and the current study appears to support of this rationale as the high frequency treatment, which corresponded with 1.5 LS, resulted in a higher leaf area rate and SLA rate per tiller compared with infrequent defoliations (Figure 2). However, this relationship could also have been an adaptive strategy by $\mathrm{Bv}$ plants subjected to more frequent defoliation, to apportion more WSC to leaf regrowth.

The result of a larger root mass at the low defoliation frequency is also in agreement with the study by Donaghy and Fulkerson [7] on Lolium perenne L., where the regrowth of roots coincided with the replenishment of WSC reserves, and greater root mass was associated with less frequent defoliation. Turner et al. [9] found similar results in Bromus willdenowii Kunth., whereby a greater partition of energy to root growth was observed under less frequent defoliation (4 LS). The root system of B. willdenowii was also identified as a store of WSC (albeit in lower amounts compared with the stubble) so a greater root mass could also act as a source of WSC for regrowth after defoliation [9,21]. If the root system of Bv is similarly an important "secondary" store of WSC, then after a drought period, plants subjected to less frequent defoliation would result in a larger root system and more WSC and these plants would be expected to recover faster than plants with a smaller root system as a result of more frequent defoliation. A fast recovery after drought would also be supported by a greater amount of WSC in the stubble (Figure 1; [12]). This interpretation is in accordance with other water stress-tolerant species, such as D. glomerata, which increases WSC during droughts, and generates a faster production recovery after re-watering [12].

In the current study, greater total root length, root area and volume measured at medium and low defoliation frequencies compared with high frequency, would be expected to enhance water capture by $\mathrm{Bv}$ from deep soil layers under field conditions, allowing plants to avoid dehydration [11], and therefore better survive drought conditions. In further support of this, PCA results showed that plant root mass was restricted under $20-25 \%$ FC when defoliated at either high or medium defoliation frequencies, compared with plants growing at 20-25\% FC and defoliated at the low frequency (Figure 2).

In New Zealand, the dry period is in summer, therefore optimal defoliation frequency in late spring is vital to prepare the plants for potential moisture stress conditions. During late spring, grasses display considerable root elongation in deeper soil horizons, while root production declines during summer [22]. Thus, the opportunity to increase soil exploration and root mass is before the summer stress period. However, this strategy would be possible only if the defoliation frequency is at least at a minimum of 3.5 LS (low defoliation frequency), to allow WSC to be allocated to root production. There was a decrease in LS under soil-water restriction in the current study, due to both slower leaf appearance rate and slower leaf elongation rate, in line with results from studies by Durand et al. [23], and Bartholomew and Williams [24]. This is further evidence that defoliation management 
should be optimal prior to the dry period expected in late spring as the ability to manipulate defoliation during a dry period, will be further exacerbated by the direct effect of low moisture levels on LS.

Frequent defoliation was detrimental to the production and energy status of tillers. In the long term, it is expected that this frequent defoliation would lead to an increase in tiller death through depletion of WSC [6], although this was not reflected in a change in tiller number per plant in the current study.

\section{Conclusions}

The research consistently demonstrated that infrequent defoliations for Bromus valdivianus Phil. resulted in plants with a larger root system and greater herbage mass. Despite the lower WSC levels for high defoliation frequency, variables such as tiller number and leaf weight rate per tiller remained unchanged.

Therefore, defoliating Bromus valdivianus Phil. at 3.5 leaf regrowth stage increased WSC reserves in the stubble, root mass and herbage mass. Bromus valdivianus Phil. pasture should be managed with a defoliation frequency based on 3.5 leaf regrowth stage during spring in order to ensure that plants have a strong root system prior to the summer dry period. This approach will help enhance summer survival and autumn regrowth.

Author Contributions: Conceptualization, J.G.-F. and I.F.L.; methodology, J.G.-F., I.F.L., D.J.D., L.M.C. and P.D.K.; formal analysis, J.G.-F.; investigation, J.G.-F.; writing-original draft preparation, J.G.-F.; writing-review and editing, I.F.L., D.J.D., L.M.C. and P.D.K. All authors have read and agreed to the published version of the manuscript.

Funding: This research received no external funding.

Data Availability Statement: The data presented in this study are available on request from the corresponding author.

Acknowledgments: The authors are grateful to staff members of the Plant Growth Unit, Massey University for their help during the measurements. We thank Massey University Research Fund (MURF) for financial support.

Conflicts of Interest: The authors declare no conflict of interest.

\section{References}

1. Keim, J.P.; López, I.F.; Balocchi, O.A. Sward herbage accumulation and nutritive value as affected by pasture renovation strategy. Grass Forage Sci. 2015, 70, 283-295. [CrossRef]

2. Fasi, V.; Mills, A.; Moot, D.J.; Pollock, K. Establishment, annual yield and nitrogen response of eight perennial grasses in a high country environment. Proc. N. Z. Grassl. Assoc. 2008, 70, 123-130. [CrossRef]

3. Moot, D.J.; Smith, M.C.; Mills, A. Relationships between sheep liveweight production and dry matter yield for lucerne-based pastures in spring. J. N. Z. Grassl. 2019, 81, 69-74. [CrossRef]

4. Harris, W. Defoliation as a determinant of the growth, persistence and composition of pasture. In Plant Relations in Pastures; Wilson, J.R., Ed.; CSIRO: Brisbane, Australia, 1978; pp. 67-85.

5. Donaghy, D.J.; Turner, L.R.; Adamczewski, K.A. Effect of Defoliation management on water-soluble carbohydrate energy reserves, dry matter yields, and herbage quality of tall fescue. Agron. J. 2008, 100, 122-127. [CrossRef]

6. Fulkerson, W.J.; Donaghy, D.J. Plant-soluble carbohydrate reserves and senescence-Key criteria for developing an effective grazing management system for ryegrass-based pastures: A review. Aust. J. Exp. Agric. 2001, 41, 261-275. [CrossRef]

7. Donaghy, D.J.; Fulkerson, W.J. Priority for allocation of water-soluble carbohydrate reserves during regrowth of Lolium perenne. Grass Forage Sci. 1998, 53, 211-218. [CrossRef]

8. Ordoñez, I.; López, I.; Kemp, P.; Donaghy, D.; Herrmann, P.; Hernández, F.; Bhatia, S. Pasture brome (Bromus valdivianus) leaf growth physiology: A six-leaf grass species. Agron. N. Z. 2017, 47, 13-22.

9. Turner, L.; Donaghy, D.; Lane, P.; Rawnsley, R. Patterns of leaf and root regrowth, and allocation of water-soluble carbohydrate reserves following defoliation of plants of prairie grass (Bromus willdenowii Kunth.). Grass Forage Sci. 2007, 62, 497-506. [CrossRef]

10. Turner, N. Adaptation to Water Deficits: A Changing Perspective. Funct. Plant Biol. 1986, 13, 175-190. [CrossRef]

11. Norton, M.R.; Malinowski, D.P.; Volaire, F. Plant drought survival under climate change and strategies to improve perennial grasses. A review. Agron. Sustain. Dev. 2016, 36. [CrossRef]

12. Volaire, F.; Norton, M.R.; Norton, G.M.; Lelievre, F. Seasonal patterns of growth, dehydrins and water-soluble carbohydrates in genotypes of Dactylis glomerata varying in summer dormancy. Ann. Bot. 2005, 95, 981-990. [CrossRef] 
13. Volaire, F.; Morvan-Bertrand, A.; Prud'homme, M.P.; Benot, M.L.; Augusti, A.; Zwicke, M.; Roy, J.; Landais, D.; Picon-Cochard, C. The resilience of perennial grasses under two climate scenarios is correlated with carbohydrate metabolism in meristems. J. Exp. Bot. 2020, 71, 370-385. [CrossRef]

14. Thomas, H.; James, A.R. Partitioning of sugars in Lolium perenne (perennial ryegrass) during drought and on rewatering. New Phytol. 1999, 142, 295-305. [CrossRef]

15. McMaster, G.S.; Wilhelm, W. Growing degree-days: One equation, two interpretations. Agric. For. Meteorol. 1997, 87, 291-300. [CrossRef]

16. Tsimba, R.; Edmeades, G.O.; Millner, J.P.; Kemp, P.D. The effect of planting date on maize: Phenology, thermal time durations and growth rates in a cool temperate climate. Field Crops Res. 2013, 150, 145-155. [CrossRef]

17. Nelson, N. A photometric adaptation of the Somogyi method for the determination of glucose. J. Biol. Chem. 1944, 153, 375-380. [CrossRef]

18. Team, R.C. R: A language and environment for statistical computing. 2013. Available online: https://www.r-project.org/ (accessed on 3 June 2019).

19. Turner, L.R.; Donaghy, D.J.; Lane, P.A.; Rawnsley, R.P. Effect of defoliation management, based on leaf stage, on perennial ryegrass (Lolium perenne L.), prairie grass (Bromus willdenowii Kunth.) and cocksfoot (Dactylis glomerata L.) under dryland conditions. 1. Regrowth, tillering and water-soluble carbohydrate concentration. Grass Forage Sci. 2006, 61, 164-174.

20. Danckwerts, J.; Gordon, A. Long-term partitioning, storage and re-mobilization of 14C assimilated by Lolium perenne (cv. Melle). Ann. Bot. 1987, 59, 55-66. [CrossRef]

21. Johansson, G. Carbon distribution in grass (Festuca pratensis L.) during regrowth after cutting-Utilization of stored and newly assimilated carbon. Plant Soil 1993, 151, 11-20. [CrossRef]

22. Parsons, A. The effects of season and management on the growth of grass swards. In The Grass Crop; Jones, M.B., Lazenby, A., Eds.; Springer: London, UK, 1988; pp. 129-177.

23. Durand, J.-L.; Onillon, B.; Schnyder, H.; Rademacher, I. Drought effects on cellular and spatial parameters of leaf growth in tall fescue. J. Exp. Bot. 1995, 46, 1147-1155. [CrossRef]

24. Bartholomew, P.; Williams, R. Effects of exposure to below-freezing temperatures, soil moisture content and nitrogen application on phyllochron in cool-season grasses. Grass Forage Sci. 2006, 61, 146-153. [CrossRef] 